\title{
EVALUATION OF INFILTRATION CAPACITY OF THE SOIL DURING APPLICATION OF ADDITIONAL IRRIGATION
}

\author{
Jobbágy J, Krištof K, Findura P, Angelovič M, Folkman $\mathbf{M}^{\mathbf{1}}$, Turan $\mathbf{J}^{\mathbf{2}}$ \\ ${ }^{1}$ Slovak University of Agriculture, Faculty of Agricultural of Engineering, Department of \\ Machines and Production systems, Tr. A. Hlinku 2 SK-949 76 NITRA, Slovakia \\ ${ }^{2}$ University of Novi Sad, Faculty of Agriculture, Department of Agricultural Engeneering, \\ Trg Dositeja Dbradovića 8, 21000 Novi Sad, Serbia \\ e-mail: jan.jobbagy@uniag.sk
}

\begin{abstract}
In this article given we specialized on the evaluation of soil infiltration ability during the application of additional watering. On the chosen location were grown potatoes of GALA variety (early). The area of the location was 6.23 ha. We chose 9 monitoring spots. The whole process was monitored during the vegetation period. At the beginning of the research of the infiltration there was the average value $12.43 \mathrm{~cm} \cdot \mathrm{s}^{-1}$, which was caused by the residual winter soil moisture and the planting of potatoes. In the second measurement which was practised after the first application of the irrigation rate and erratum terra, the value of infiltration rapidly rose to $50.24 \mathrm{~cm} . \mathrm{s}^{-1}$. It was caused by the insufficiency of the irrigation water and the rain water. Immediately after the application of the irrigation rate, we made the third measurement. The results were obvious, when the value decreased by $51 \%$ (from $50.24 \mathrm{~cm} \cdot \mathrm{s}^{-1}$ to $24.43 \mathrm{~cm} \cdot \mathrm{s}^{-1}$ ). The results were only changed partially, which was caused by the right application of irrigation rates. Before the gathering the irrigation rate was not applied, what was manifested by raising value of infiltration of soil from the fifth measurement. The last measurement manifested the depression of infiltration caused by the atmospheric precipitation, which were three days before the measurement (2012-1009). In conclusion, we can state that the irrigation rate and its influence on infiltration ability of soil are not negligible.
\end{abstract}

Keywords: irrigation rate, infiltration, evaluation, watering.

\section{INTRODUCTION}

The process of water penetration into the soil is called infiltration and it happens mostly through its surface. From the hydrological point of view the most interesting infiltration is from precipitation. From the intensity of infiltration the formation of surface runoff depends and it's associated with soil erosion. The aim is to create such a conditions which allows that the greatest amount of rainfall are infused into the soil so needed for plants growth (Velebný et al., 2000).

Infiltration is the process through which the water enters the soil and it can be described by infiltration rate which in soil science is the rate at which the soil is able to absorb water from rainfall or irrigation. Infiltration rate (capacity) of the soil is measured by the rate of water column displacement in mm per unit of time $\left(\mathrm{mm} . \mathrm{s}^{-1}\right)$, or in millilitres per time unit $\left(\mathrm{mL} . \mathrm{s}^{-1}\right)$. Overall, the more water soil absorbs, the more it rate reduces in advance. 
If rainfall exceeds the infiltration rate, drainage of water into the soil will be slower. Infiltration rate can be measured by device called infiltrometer. Measurements and evaluation of infiltration by hydraulic conductivity is shown on Figure 1 wherein the cumulative infiltration values ranged from 0.26 to $0.84 \mathrm{~cm}$ (Kukan et al., 2008).

Infiltration can be measured by several methods such as block furrow infiltrometer, ring infiltrometer, respectively by devices that measure the inflow and outflow of water (Davis and Frey, 1963). The most commonly used became a ring infiltrometer (Hills, 1970). Measurements of infiltration rate are different in the method of water application to the soil surface. There are three most basic ways of measuring infiltration (Schulin, 1995) namely, reservoir method (water usually soak in from two concentric cylinders or large infiltrometers with different plan shape), tenziometric method (in this method the infiltration water passes through the porous plate with low permeability) and method of artificial rain (in this method, measurements of infiltration are made indirectly).

Among modern measurement methods includes the measurement by Minidiscs infiltrometer. The advantage of this measurement of infiltration is its low water consumption of about $135 \mathrm{ml}$ per one measurement. The water infiltrates into the soil through a semi-permeable and stainless steel membrane and on water infiltration into the soil is read on the scale.

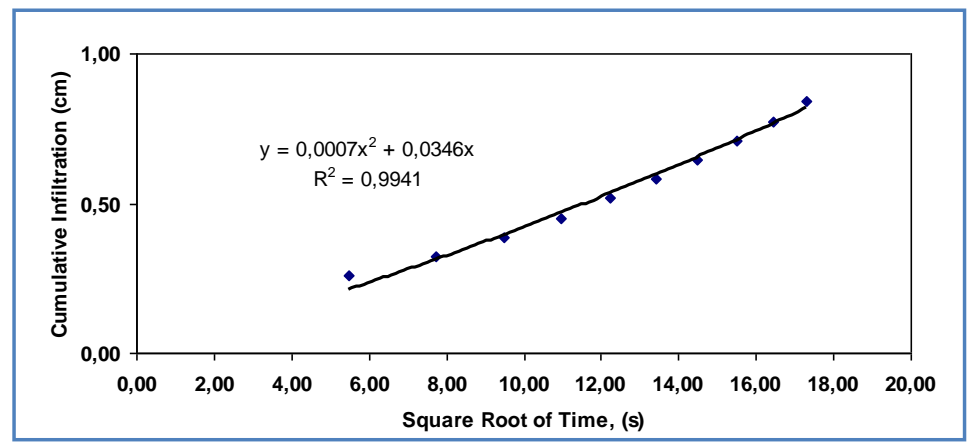

Fig. 1. Dependence of cumulative infiltration on the square root of time (Kukan et al., 2008)

\section{MATERIAL AND METHODS}

The aim of the study was to observe the effect of irrigation dose and others working operations on infiltration rate during growing season. On a given plot area of 6.23 ha were cultivated potato, Gala varieties. There were selected 9 observation points on the selected field where infiltration measurement were conducted by MiniDisc Infiltrometer (DECAGON DEVICES, Figure 2 A). For recording of the field boundaries and position of observation points were used handheld satellite navigation system Garmin Oregon 450 (Figure 2 B).

MiniDisc Infiltrometer consists of polycarbonate tubes with a diameter of $31 \mathrm{~mm}$ and a height of $327 \mathrm{~mm}$. The tube is divided into two parts which are filled with water. The upper part is for setting air intake using adjustable steel tube (depending on soil type). The water from the lower part is infiltrated into the soil through a semi-permeable stainless steel membrane disposed on the bottom of the tube. The lower part is also equipped with a scale in millilitres from which are subtracted the volume of infiltrated water. Measurements were 
carried out following the procedure as described in procedure manuals. MiniDisc Infitrometer package provides also the software for processing results.

a)
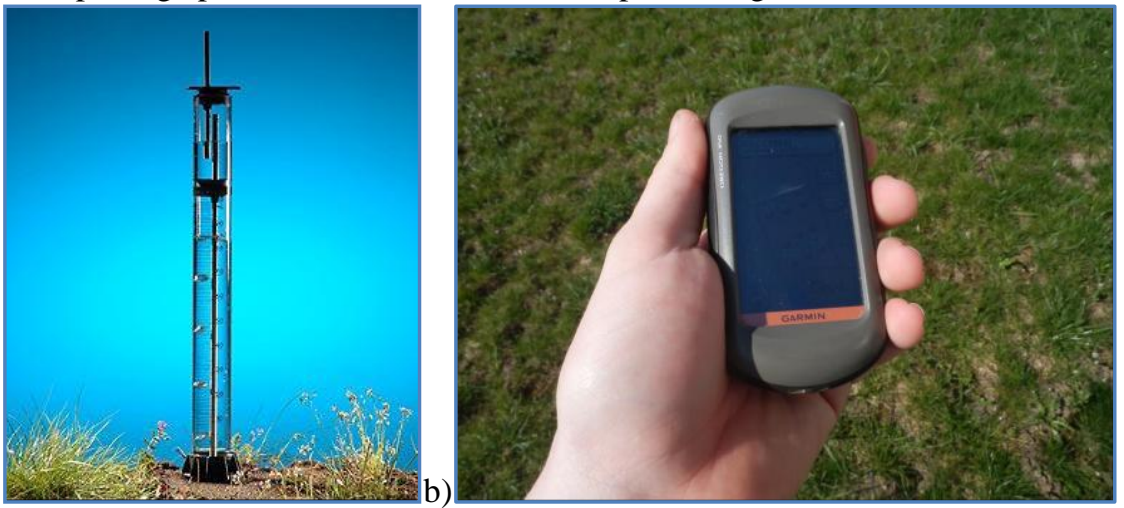

Figure 2 MiniDisc Infiltrometer (A) and GPS unit (B)

Hydraulic conductivity of the soil can be defined as: „how many meters of water per day seep down into the soil, namely by the gravity or pressure gradient unit“(Kirkham, 2005).

The hydraulic conductivity of the soil is calculable by various methods. One of them is the method for calculating infiltration and hydraulic conductivity of soil which was set by Zhang (1997). This method requires the measurement of cumulative infiltration with respect to time and determining the results by function.

$$
I=C_{1} t+C_{2} \sqrt{t}
$$

where:

$\mathrm{C}_{1}$ - parameter of function associated with hydraulic conductivity $\left(\mathrm{m} . \mathrm{s}^{-1}\right)$

$\mathrm{C}_{2}$ - parameter of function associated with sorptive capacity of soil $\left(\mathrm{m} . \mathrm{s}^{-1 / 2}\right)$

The hydraulic conductivity of the soil $(k)$ is then calculated by function:

$$
k=\frac{C_{1}}{A_{f}}
$$

where: of time.

$\mathrm{C}_{1}$ - is the slope of the curve of cumulative infiltration depending on the square root

$A_{f}$ - is van Genuchton's parameter which is based on the settings of air intake tube and the soil type and it is provided by manufacturer's manual.

After calculating hydraulic conductivity $(k)$ for each monitoring point, a map of hydraulic conductivity of soil was constructed. 


\section{RESULTS AND DISCUSSION}

Measurements were carried out on a plot where potato varieties Gala (early) were planted and owned by private farmer Zdenko Černay, located in Senec. The selected plot is part of a large estate with an area of 81 ha in the administrative territory of Vel'ký Biel. The land is under irrigation with built-in distribution of irrigation water which comes from the nearby lake - a former gravel pit. With regards to the soil and climatic conditions selected field belongs to corn production area. It is a very warm and very dry lowland region, where the main soil unit is typical black soil, carbonated on carbonate alluvial sediments, medium duty - loamy.

The outcome of our research was to evaluate the impact of irrigation dose and work activities during the growing season on the infiltration capacity of the soil expressed by hydraulic conductivity. The field was fertilized during the pre-plan cultivation by ammonium nitrate with dose of $300 \mathrm{~kg} \cdot \mathrm{ha}^{-1}$. Fertilizers were incorporated into the soil by compactor, after which potatoes were planted by potatoes planter GRIME GL 34T (4-lines) and followed by turn-up operation by covering machine GRIME.

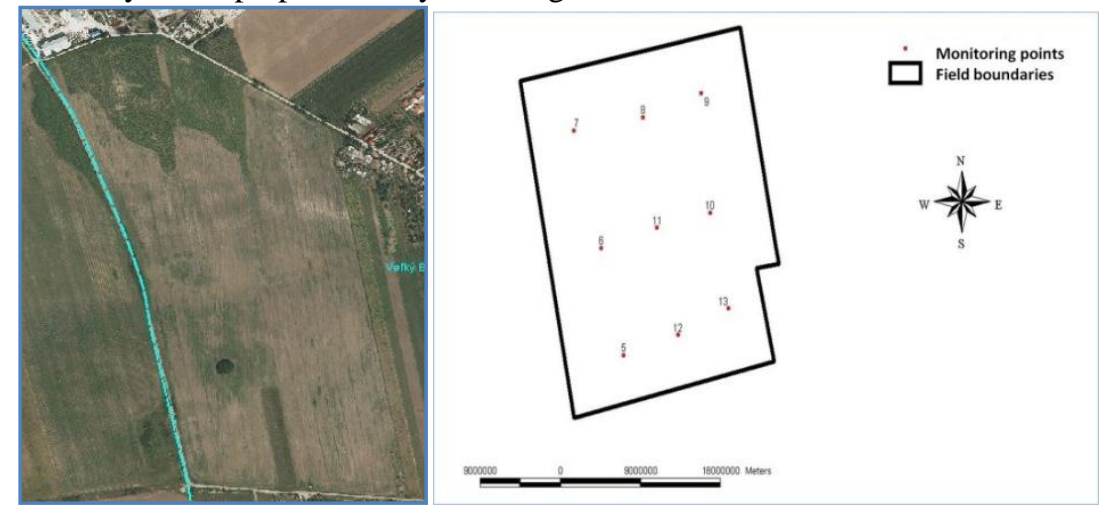

Figure 3 Selected field and monitoring points.

After these operations first measurement took place. Figure 4 shows the dependence of cumulative infiltration on the square root of time. The results are valid for the monitoring point 1 . It showed almost a fluent change of cumulative infiltration with curve slope parameter $\mathrm{C}_{1}$ determined according to the methodology as 0,0006 . The value of van Genuchton's parameter A, determined according to the methodology enclosed to MiniDisc infiltrometer, was 7 for given soil type. After calculation of these results hydraulic conductivity $(k)$ was concluded as it is showed in Table 1. Negative values reflect deceleration during the infiltration which occurred in the monitoring point 4 . In the monitoring point 8 was value of infiltration already positive as in the rest of field area. It is possible to conclude from mentioned figure that the field consist of areas passing through it with different characteristics in comparison to the edges of the field. The low value of the calculated weighted average of hydraulic conductivity $\left(12.44 \mathrm{~cm} . \mathrm{s}^{-1}\right)$ expresses the remaining reserve of winter moisture which was able to get into the shallow layers of the soil during extensive operations connected with potatoes planting and it's covering with additional soil. 


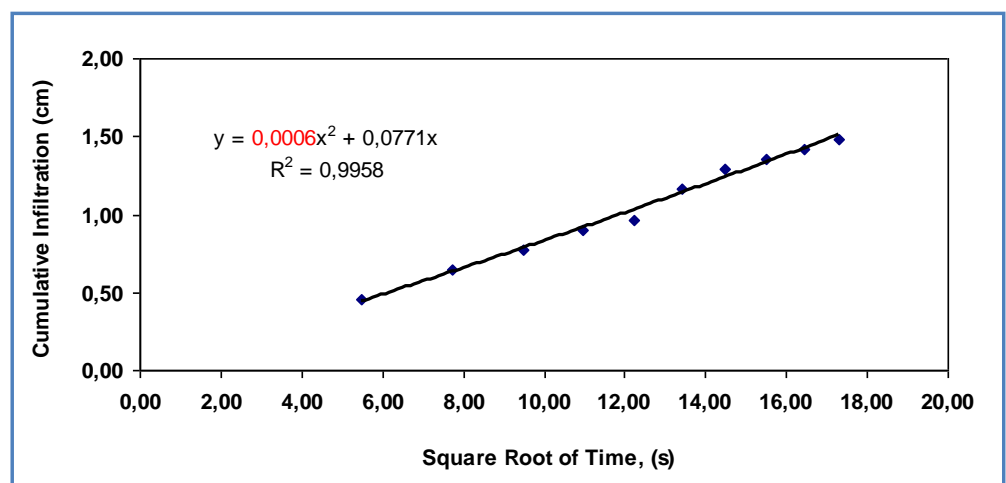

Fig. 4. Dependence of cumulative infiltration on the square root of time.

Table 1 Hydraulic conductivity $\left(1^{\text {st }}\right.$ measurement $)$.

\begin{tabular}{|c|c|c|c|}
\hline Measurement point & $\mathrm{C}_{1}$ & $\mathrm{~A}_{\mathrm{f}}$ & $k$ \\
\hline 1 & 0.0006 & 7 & $8.57 .10^{-5}$ \\
\hline 2 & 0.0014 & 7 & $20.10^{-5}$ \\
\hline 3 & 0.0007 & 7 & $10.10^{-5}$ \\
\hline 4 & -0.0001 & 7 & $-1.43 .10^{-5}$ \\
\hline 5 & 0.0018 & 7 & $25.71 .10^{-5}$ \\
\hline 6 & 0.0006 & 7 & $8.57 .10^{-5}$ \\
\hline 7 & 0.0007 & 7 & $10.10^{-5}$ \\
\hline 8 & 0.0003 & 7 & $4.29 .10^{-5}$ \\
\hline 9 & 0.001 & 7 & $14.28 .10^{-5}$ \\
\hline
\end{tabular}
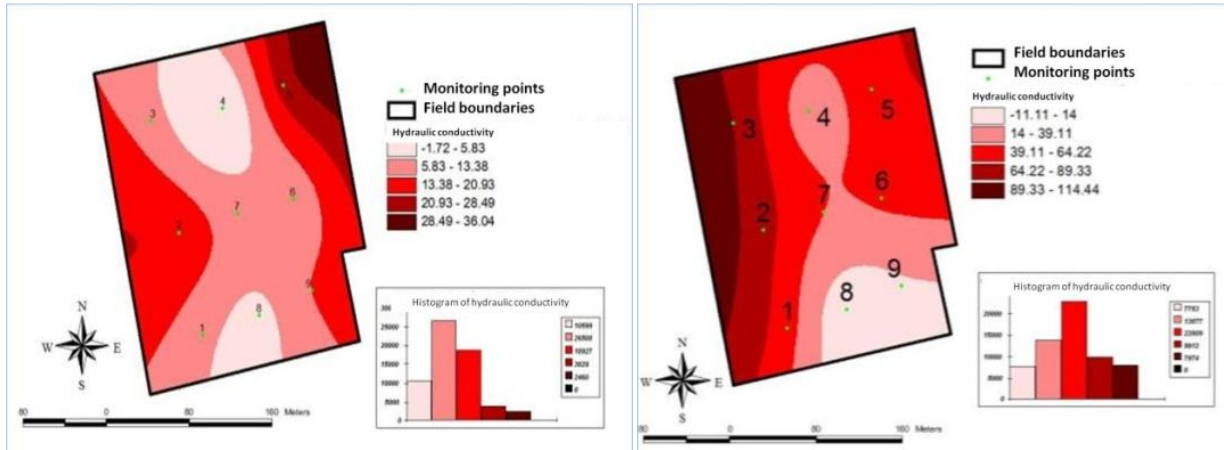

Fig. 5. Map of hydraulic conductivity of soil ( $1^{\text {st }}$ and $2^{\text {nd }}$ measurement).

Before the second measurement irrigation dose of $30 \mathrm{~mm}$ was applied. It was followed by another turn-up and covering potatoes with additional soil. Later, when the weeds emerged pesticide spraying took place and there we applied Sencor (dose of $1 \mathrm{~kg} \cdot \mathrm{ha}^{-}$ ${ }^{1}$ ) and Garland Forte (dose of $0.81 . \mathrm{ha}^{-1}$ ). Weighted average of hydraulic conductivity at the second measurement has increased more than four times $\left(50.25 \mathrm{~cm} . \mathrm{s}^{-1}\right)$. Graphical display of the results can be seen in Figure 5. The measured values indicate reduced reserves of soil 
moisture in the shallow layers which resulted in increased hydraulic conductivity. Sometime after the second measurement it was followed by supplementary irrigation with dose $40 \mathrm{~mm}$. After the irrigation third measurement was conducted. The last two measurements (second and third) were performed three days apart. It means a significant effect of high doses of irrigation on hydraulic conductivity where the value of weighted average decrease from $50.25 \mathrm{~cm} . \mathrm{s}^{-1}$ on dry soil to $24.43 \mathrm{~cm} . \mathrm{s}^{-1}$ on soil saturated with irrigation water. The decrease in hydraulic conductivity has been $51 \%$. After third irrigation dose was applied, fourth measurement was carried out with distance in time about 2 weeks. Weighted average of hydraulic conductivity was $25.26 \mathrm{~cm} \cdot \mathrm{s}^{-1}$ what means only slight decrease in comparison with third measurement on $0.83 \mathrm{~cm} . \mathrm{s}^{-1}$. Measurements were not done immediately after irrigation dose however the value of hydraulic conductivity indicates that there were still sufficient reserves of soil moisture. It can be concluded that the distribution of irrigation doses for this period has been optimal.

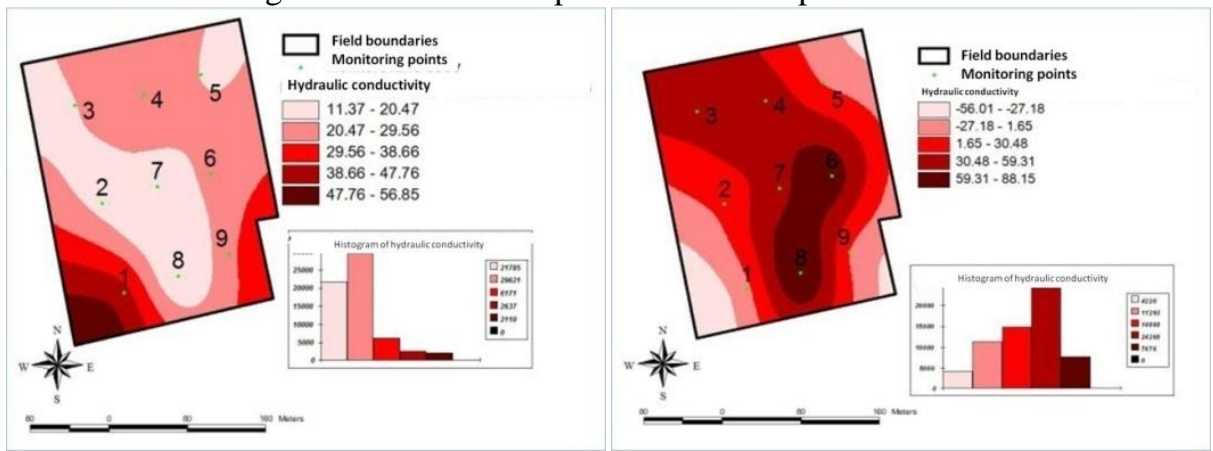

Fig. 6. Map of hydraulic conductivity $\left(3^{\text {rd }}\right.$ and $4^{\text {th }}$ measurement $)$.

Before the fifth measurement there were no additional irrigation on the field and crops were harvested by potatoes harvesting machine GRIME SE $170-60$. The fifth measure has taken place on the field without a crop and without post-harvest treatment of soil, containing crop residues. Average value of hydraulic conductivity in the fifth measurement was $41.01 \mathrm{~cm} . \mathrm{s}^{-1}$. Increased value of hydraulic conductivity indicates a reduction in soil moisture reserves and application of irrigation dose would be then recommended, what has not taken place with regard to the period of harvest.

The last working operation on the field was soil tillage and crop residues incorporation into the soil with disk-harrow Grégoire Bessou. After these operations the sixth measurement took place. Before the last measurement an increased hydraulic conductivity was expected due to the loosened soil surface but three days prior the measurement there were an excessive rainfall. Increased soil moisture was observed in soil layers and decreased hydraulic conductivity occurs (weighted average $24.66 \mathrm{~cm} . \mathrm{s}^{-1}$ ).

Soil erosion is a major environmental threat to sustainability and production capacity of agriculture. In the last 40 years almost one third of the world's arable land was destroyed by soil erosion (Pimentel et al., 1995).

Soil erosion affects the dynamics of carbon in the soil. Ecological and environmental effect erosion indicated by changes in soil carbon ensures a serious and experimental reduction of soil carbon and minimize the transport of sediment to the world's water channels (Lal, 1995). 


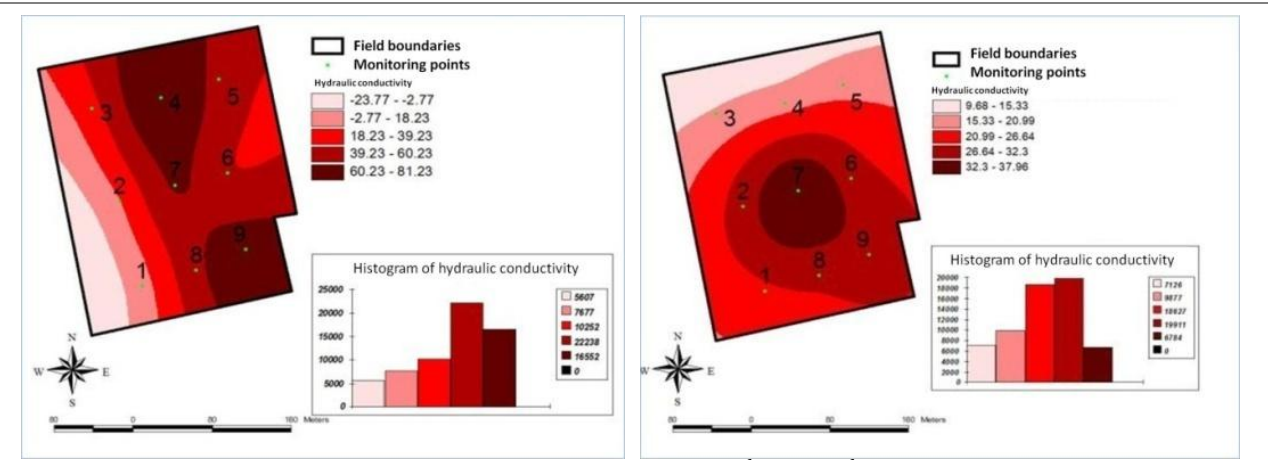

Fig. 7. Map of hydraulic conductivity ( $5^{\text {th }}$ and $6^{\text {th }}$ measurement $)$.

The infiltration of water into the soil is such a characteristic of the soil, which describes the ability of water penetration into the soil. To its specification a several methods exists. The measurement results will help to determine the effect of soil erosion and its control (Sindelar et al., 2007).

One of the main reasons for soil conservation technologies integration into the system of soil management is currently decrease in the flooding of the surface layer of soil and its drainage (Shipitalo et al., 2000).

Economically effective way to prevent water pollution and its flush out is the tillage which leaves a crop residues on the soil surface (Ginting et al., 2003) also called conservation tillage.

In application of supplementary irrigation and determination of its doses it is needed to determine hydrolimits, soil moisture and monitoring of precipitation and address their effect on the erosion. One of the effects which can maintain the erosion is to keep sufficient infiltration capacity of the soil. Adversely affect on the infiltration capacity of the soil are an extremely high irrigation doses but also use of inappropriate machinery to its application. It can cause the degradation of soil surface by improper spraying of the irrigation water which is caused by kinetic energy of the drops falling on the soil surface.

\section{CONCLUSION}

The issue of the paper was to assess the effect of irrigation not only benefits but also work activities during the growing season on the infiltration capacity of the soil. The infiltration is closely related to the hydraulic conductivity of the soil and according to our findings is mainly dependent on soil moisture. It was clearly confirmed by measurements taken immediately before and immediately after supplementary irrigation when the soil hydraulic conductivity decreased by up to $51 \%$. Progressively as the soil surface dries out hydraulic conductivity was increasing. The last measurement not confirmed our expectations whereas shown no elevation in hydraulic conductivity after the last measurement which should result in a change of soil structure by performing stubble breaking. This phenomenon could be caused by several factors such as rainfalls as a result of impact on the hydraulic conductivity which obscure the effect of stubble breaking. It would be interesting to examine, in this case, the whole soil horizon and to conclude further consequences. 


\section{REFERENCES}

[1] DAVIS, J.R. - FREY, A.W. 1963. Measurement of infiltration rates in irrigated furrows. In Transactions of the ASAE. Annual 6. 1963. Number 4.

[2] GINTING, D. - MONCRIEF, J.F. - GUPTA, S.C. 2003. Performance of a variable tillage systems based on interaction with landscape and soil. Precision Agriculture Vol. 4. No.1. Kluwer Academic Publishers. Netherlands. 2003. ISSN 1385-2256. p. 19-34.

[3] HILLS, C.R. 1970. The determination of the infiltration capacity of field soil using cylinder infiltrometer. In: British Geomorfological Research Group. Tech. Bull. No.3. 1970.

[4] KIRKHAM, M.B. 2005. Principles of Soil and Plant Water Relations. Elsevier Academic Press: Burlington. MA. 2005. pp. 145-172.

[5] KUKAN, P. - JOBBÁGY, J. - BUC, M. - FINDURA, P. 2008. Infiltration ability of soil as an indicator of its variability. In: X. Medzinárodná vedecká konferencia mladých. Zborník z medzinárodnej vedeckej konferencie. CD. Praha. 16.-18. Septembra 2008. s. 130-135. ISBN 978-80-213-1812-0.

[6] LAL, R. 1995. Global soil erosion by water and carbon dynamics. In: Reicosky, D.C. - Lindstrom, M.J. - Schumacher, T.E. - Lobb, D.E. - Malo, D.D. 2005. Tillage-induced $\mathrm{CO}_{2}$ loss across an eroded landscape. Soil \& Tillage Research. Vol. 81. p 183-194.

[7] PIMENTEL, D. - HARVEY, C. - RESOSUDARMO, P. - SINCLAIR, K. - KURZ, D. - MCNAIR, M. - CRIST, S. - SHPRITZ, L. - FITTON, L. - SAFFOURI, R. - BLAIR, R. 1995. Environmental and economic costs of soil erosion and conservation benefits. Science 267. p. 1117-1123. Available on internet: http://www.sciencemag.org/cgi/content/abstract/sci;267/5201/1117

[8] SCHULIN, R. 1995. Bodenschutz-Kutz. Institut f. Terrestrische ökologie. ETHZ. 1995

[9] SHIPITALO, M.J. - DICK, W.A. - EDWARDS, W.M. 2000. Conservation tillage and macropore factors that affect water movement and the fate of chemicals. Soil \& Tillage Research. Vol. 53. Nos. 3-4. p. 167183

[10] SINDELAR et al. 2007. Hodnocení infiltrace vody do půdy. In IX. Medzinárodná vedecká konferencia mladých 2007. Zborník z medzinárodnej vedeckej konferencie. CD. Nitra 10. - 11. Október 2007. ISBN 978-808069-946-8

[11] VELEBNÝ et al. 2000. Vodný režim pôdy. STU Bratislava. 2000. ISBN 80-227-1373-2

[12] ZHANG, R. 1997. Determination of soil sorptivity and hydraulic conductivity from the disk infiltrometer. Soil Science Society of America Journal. 61. p. 1024-1030.

\section{OCENA KAPACITETA INFILTRACIJE NA ZEMLJIŠTE TOKOM MERE NAVODNJAVANJA}

\section{Jobbágy J, Krištof K, Findura P, Angelovič M, Folkman $M^{1}$, Turan $\mathbf{J}^{2}$}

\section{REZIME}

U ovom članku specijalno je data ocena kapaciteta infiltracije kao sposobnosti zemljišta tokom dodatnog navodnjavanja. Na odabranim lokacijama gajen je rani krompir sorte Gala. Površina lokacije je 6.23 hektara. Izabrano je 9 monitoring mesta. Ceo proces je praćen u toku vegetacije . Na početku istraživanja infiltracija prosečna vrednost iznosila je $12,43 \mathrm{~cm} . \mathrm{s}^{-1}$, koji je uzrokovan od zaostale vlage zemljišta usled zime i sađenja krompira. U drugom merenju koje je praktikovano nakon prve primene norme navodnjavanja i Erratum Terra, vrednost infiltracije brzo je porastao na $50,24 \mathrm{~cm} . \mathrm{s}^{-1}$. To je uzrokovano usled insuficijencije vode od navodnjavanja i kišnice. Odmah nakon trećeg navodnjavanja, urađeno je merenje. Rezultati su bili očigledni, vrednost je smanjena za $51 \%$ (sa $50.24 \mathrm{~cm} . \mathrm{s}^{-1}$ na $24.43 \mathrm{~cm} . \mathrm{s}^{\mathrm{s}}$ $\left.{ }^{1}\right)$. Rezultati su samo delimično promenjeni, što je uzrokovalo pravu primenu norme navodnjavanja. Pre merena, navodnjavanje nije bilo primenjeno, šta se manifestuje u podizanju vrednosti infiltracije zemljišta kod petog merenja. Poslednje merenje manifestuje depresiju infiltracije prouzrokovane atmosferskim padavinama, koje su bile tri dana pre merenja (2012-10-09). U zaključku, može se konstatovati da uticaj količine navodnjavanja na stopu infiltracije nije zanemarljiv.

Ključne reči: norma navodnjavanja, infiltracija, ocena, navodnjavanje.

Acknowledgement:The paper reflects the results obtained within the research project VEGA no. $1 / 0786 / 14$, Effect of the environmental aspects of machinery interaction to eliminate the degradation processes in agro technologies of field crops ". 